\title{
Development and lipid composition of the harpacticoid copepod Nitocra spinipes reared on different diets
}

\author{
Gregory M. Weiss ${ }^{1}$, George B. McManus ${ }^{2, *}$, H. Rodger Harvey ${ }^{3}$ \\ 'Ocean Process Analysis Lab, University of New Hampshire, Durham, New Hampshire 03824, USA \\ ${ }^{2}$ Dauphin Island Sea Lab, Marine Environmental Sciences Consortium, University of South Alabama, Dauphin Island, \\ Alabama 36528, USA \\ ${ }^{3}$ Chesapeake Biological Laboratory, Center for Environmental and Estuarine Studies, University of Maryland System, \\ Solomons, Maryland 20688, USA
}

\begin{abstract}
We reared the harpacticoid copepod Nitocra spinipes on diets of bacteria, a diatom, or a macroalga, evaluating survivorship and growth in short-term ( $\leq 1$ generation) experiments. Lipid content of the copepods and their diets was measured and used as an index of nutrition. Although growth, survivorship and lipid content of $N$. spinipes were significantly greater when fed the diatom, which had the highest lipid content of the 3 diets, the copepod was able to develop from egg to adult when fed a lipid-poor bacterial diet. Furthermore, this species was able to go through developmental molts without the addition of food ( 6 individuals from a starved cohort of 25 made it to at least copepodite stage 1), suggesting the uptake of dissolved organic matter for growth. This widespread estuarine benthic copepod apparently has the ability to survive on diverse and nutritionally poor diets, a quality that is useful in a variable, detritus-dominated environment
\end{abstract}

KEY WORDS: Copepod · Feeding · Lipid · Bacteria - Nutrition

\section{INTRODUCTION}

Harpacticoid copepods comprise a large proportion of the meiofauna in many marine benthic communities (Hicks \& Coull 1983). They have been described as an essential link to upper trophic levels in benthic communities and are a common food for fish larvae in aquaculture. Although it has been argued that harpacticoids are the most important component in the diets of some larval and juvenile fish (Alheit \& Scheibel 1982, Hicks \& Coull 1983), their overall role in nutrient and energy transfer in marine benthic food webs is not well quantified.

Studies on the trophodynamics of harpacticoids have revealed that they are often indiscriminate feeders,

\footnotetext{
- Addressee for correspondence. Present address: Department of MarineSciences, University of Connecticut, Groton, Connecticut06340,USA.E-mail:gmcmanus@uconnvm.uconn.edu
}

utilizing dissolved and particulate organic matter, microalgae, ciliate protozoa and copepods (Heinle et al. 1977, Rieper 1978, Rieper \& Flotow 1981, Poulet 1983. Decho \& Fleeger 1988, Lazzaretto \& Salvato 1992). Much is known about the dietary components of harpacticoids, but the nutritional value of these components is not well understood.

Nitocra spinipes is a common harpacticoid species found in brackish-water environments throughout the world (Lang 1948, Muus 1967, Noodt 1970, Wulff 1972 , Gopalan 1977). It is euryhaline, with a salinity tolerance well beyond the range of most natural salinity fluctuations (Wulff 1972), as is commonly found in otizer harpacticoids (Ranade 1957). Laboratory cultures reveal it has a wide range of suitable foods (Gopalan 1977, Weiss pers. obs.)

The ontogeny of Nitocra spinipes consists of 6 nonpelagic naupliar stages and 6 copepodite stages, with stage VI corresponding to the adult. Generation time 
typically is 10 to $14 \mathrm{~d}$ at 25 to $27^{\circ} \mathrm{C}$ (Weiss pers. obs.). The number of eggs per brood varies between 15 and 30 (Muus 1967. Weiss pers. obs.) with a female producing 1 to 3 broods per fertilization.

We set out to answer 3 questions concerning the nutrition of this copepod. First, can Nitocra spinipes develop from egg to adult on a diet consisting exclusively of bacteria? Previous observations that harpacticoid copepods can be cultured on bacteria would seem to contradict the established idea that the Crustacea have strict dietary requirements, especially for lipids such as sterols and polyunsaturated fatty acids, which are usually not found in bacteria (Rieper 1978, Goad 1981, Lechevalier \& Lechevalier 1988). Second, how well does a bacterial diet support growth and survivorship, compared with other common foods (a diatom and a macroalga)? Third, is dietary lipid content closely correlated with growth and lipid content of the copepods, as is the case with many other crustaceans (e.g. Provasoli et al. 1970, Lee et al. 1971, Hakanson 1984, Ahlgren et al. 1990)?

\section{MATERIALS AND METHODS}

Cultures of Nitocra spinipes were started from individuals obtained from the lower Patuxent River, a tributary of Chesapeake Bay, USA. They were maintained for multiple generations in the laboratory on a diet of mixed microalgae (the diatom Thalassiosira weissflogii and the prymnesiophyte Isochrysis galbana) plus any associated bacteria in the cultures. Gravid females were taken from these cultures for the feeding experiment. The experiment compared growth and survivorship on the diatom $T$ weissflogii, the macroalga Ulva sp., and a gram-negative bacterium isolated from the river. The 3 diets were chosen to cover a wide range in chemical composition and to reflect food types commonly found in Chesapeake Bay. Based on the results of the feeding experiment, a second experiment was done to examine more closely naupliar survivorship and development under starvation.

Preparation of diets. Bacteria were isolated from the lower Patuxent River on enriched seawater agar using a streak plate technique described in Benson (1990). A yeast-tryptone seawater medium was inoculated with single colonies collected from the agar plates and incubated at $27^{\circ} \mathrm{C}$ on a countertop shaker. After $24 \mathrm{~h}$ the bacteria were centrifuged $(20 \mathrm{~min}$ at $6000 \mathrm{rpm}, 3800 \times$ $g)$, washed with deionized water to remove salt and medium, and centrifuged again. The pellets were transferred to $20 \mathrm{ml}$ scintillation vials and freeze-dried. The isolate used in the feeding experiment was identified as a gram-negative rod, but was not characterized further The centric diatom Thalassiosira weissflogii, obtained from non-axenic, unialgal cultures maintained at Chesapeake Biological Laboratory, was centrifuged, washed and freeze-dried as described above. Ulva sp. was collected from local waters, freeze-dried, ground, and sieved into $<240 \mu \mathrm{m}$ diameter particles.

Bacteria, diatom, macroalga feeding experiment. Treatments in this experiment (copepods fed either diatoms, macroalgae, or bacteria, plus a starved control) were replicated 4 times. The starved controls consisted of only filtered, autoclaved seawater. Five gravid females per replicate were placed in $200 \mathrm{ml}$ plastic containers filled with $50 \mathrm{ml}$ of $0.45 \mu \mathrm{m}$ filtered and autoclaved seawater (salinity $=15$ psu). The containers were maintained at 25 to $27^{\circ} \mathrm{C}$, a temperature range commonly used in previous studies (e.g. Gopalan 1977). Feeding of the diet treatments initially consisted of $50 \mathrm{\mu g}$ (dry weight) of food per container per day. After hatching of nauplii, $500 \mu \mathrm{g}$ of food per container was given daily. Copepods were collected every other day on a $64 \mu \mathrm{m}$ mesh, then gently washed off the mesh into clean water supplied with food. On days when water was not changed, $10 \mathrm{ml}$ water samples were taken from each container, stained with acridine orange, and examined under an epifluorescent microscope to assess bacterial or protozoan contamination (Hobbie et al. 1977). At the conclusion of the $14 \mathrm{~d}$ experiment, the copepods were narcotized with MS222 (Durbin et al. 1990), separated into 3 developmental stages (nauplii, copepodite, and adult) and counted. We did not measure clutch size or number of clutches per female separately; thus changes in abundance were due to combined differences in fecundity, development and survival on the different diets. One-way ANOVA and Fisher's multiple comparison test $(\alpha=$ 0.05 ) were used to quantify differences in copepod abundance between treatments.

Starvation experiment. Because some copepods survived and even continued development in the starved controls during the first experiment, we conducted a second experiment to evaluate the effects of starvation when cannibalism was not possible. We started with 25 nauplii hatched from the same clutch. They were separated, rinsed, and placed in individual wells filled with $1 \mathrm{ml}$ of $0.45 \mu \mathrm{m}$ filtered, autoclaved seawater. Survivors were identified to stage and transferred to clean filtered seawater every second or third day until the last copepod died on Day 23

Lipid extraction and analysis. Individuals within each treatment in the first experiment were pooled and collected by filtration through combusted glass-fiber filters (Whatman GF/C) for lipid analysis. Copepods were washed with deionized water and transferred 3 times before filtering to remove organic debris. Samples of each freeze-dried diet were also prepared for lipid analysis. 
Extraction of lipids was carried out using procedures described in Harvey et al. (1987). Total neutral lipid content and class composition (copepod samples only) were measured using a thin layer chromatographyflame ionization detection system (TLC-FID; Volkman et al. 1986, Parrish 1987). An aliquot of the lipid extract was examined further to determine individual sterols present in adult copepods by gas chromatography, using methods given in Harvey \& McManus (1991). For all adult copepods, cholesterol (5-cholest-5-en-3ol) was the only sterol detected.

\section{RESULTS}

\section{Bacteria, diatom, macroalga feeding experiment}

There were significant differences in the yield $(\mathrm{p}<$ 0.0001 ; all developmental stages combined) of copepods raised on the different diets (Fig. 1). The abundance of copepods that had been fed the diatom Thalassiosira weissflogii was significantly greater $(p<$ 0.0001 ) than that of individuals in the other treatments (Fig. 1). The total number of surviving offspring in the diatom treatment was $35 \%$ greater than in the bacterial and macroalgal treatments, and $80 \%$ greater than in the starved control. Treatment error (coefficient of vari-

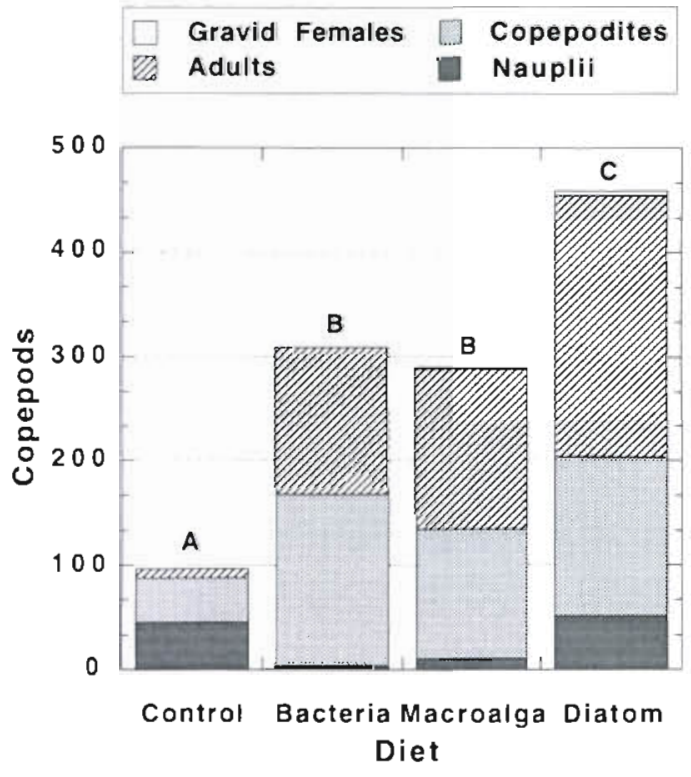

Fig. 1. Nitocra spinipes. A.bundance of copepods for each diet treatment after the $14 \mathrm{~d}$ feeding experment. Bars represent treatment means $(n=4)$ and are divided into the 4 developmental stages: nauplii, copepodites, adults, gravid females. Error within treatments is given in the text. Bars with same letters were not significantly different $(\alpha=0.05$; Fisher's multiple comparison test)

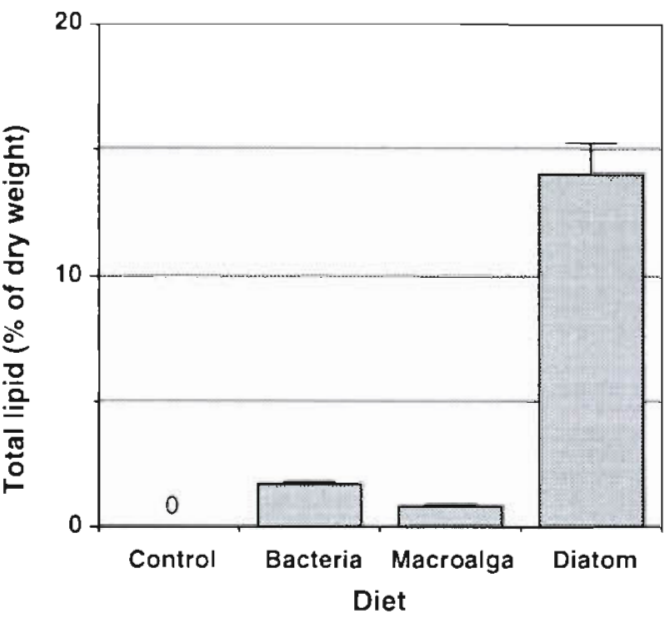

Fig. 2. Total lipid content of the 4 diet treatments. Lupid is expressed as a percentage of the dry weight of each diet

ation) was $11 \%$ for the control and $<8 \%$ for the other treatments. A second generation of gravid females was apparent only among copepods fed the diatom diet. No significant difference in abundance $(p=0.2197)$ was detected between copepods reared on Ulva sp. and the bacterial diet. The number of individuals in the starved control was significantly lower $(p<0.0001)$ than that of the other 3 treatments. There was no bacterial or protozoan contamination apparent in the treatments, although these diets were not initially axenic.

The diatom diet had a much higher proportion of lipid per milligram dry weight than the bacteria or macroalga diet (Fig. 2). Similarly, copepods fed the diatom contained over 5 times more total neutral lipid per individual than that recorded for the other 3 treatments (Fig. 3a). Triacylglycerol, which made up $72 \%$ of the total neutral lipid in copepods fed the diatom, was not detectable in copepods fed the other diets (Fig. 3b). Copepods fed the diatom also had approximately 3 times as much cholesterol as those fed the bacterium or Ulva sp. Sterol comprised 32 and $43 \%$ of the neutral lipid in copepods fed Ulva sp. and bacteria, respectively. All of the neutral lipid detected in the starved copepods was present as cholesterol.

\section{Starvation experiment}

When nauplii from a single clutch were starved in individual wells separate from other nauplii, most perished within the first week $(50 \%$ survival at ca 5 di Fig. 4). The last survivor lasted $22 \mathrm{~d}$. Despite complete lack of particulate food, however, some individuals passed through successive molts of the naupliar stages and became copepodites. Of the original 25 nauplii, $24 \%$ made it to the copepodite stage 


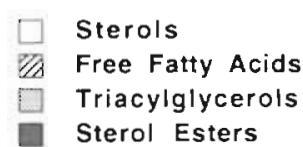

(a)

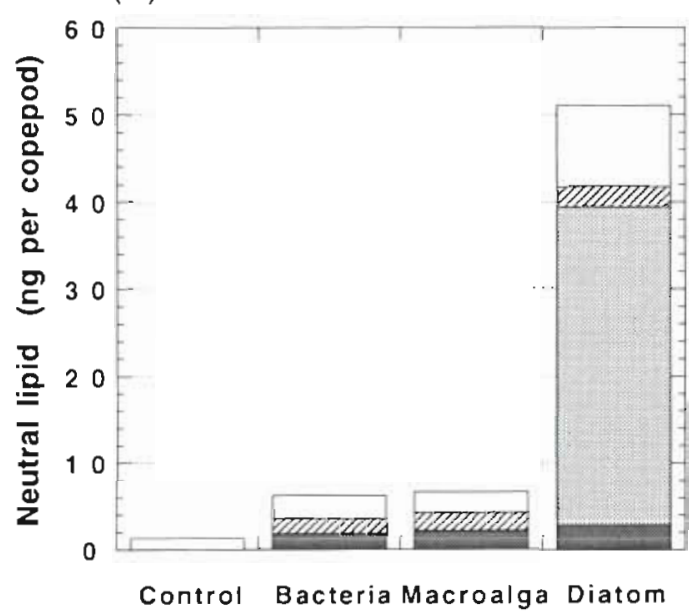

(b)

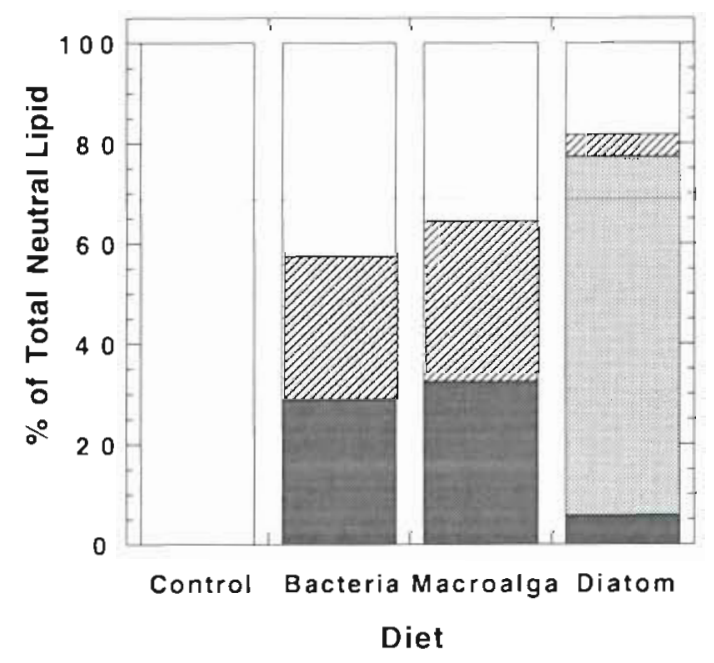

Fig. 3. Nitocra spinipes. Abundance of neutral lipids in copepods after $14 \mathrm{~d}$ feeding expenment as (a) absolute amount (ng lipid per copepod, all stages combined) and (b) as a percent of total lipid. The control treatment was copepods reared in filtered, autoclaved seawater only

\section{DISCUSSION}

Our experiments with Nitocra spinipes were motivated initially by reports that some harpacticoids have been cultured successfully on diets rnnsisting exclusively of bacteria (e.g. Tisbe holothuriae and Paramphiascella vararensis; Rieper 1978). This is puzzling because with few exceptions bacteria lack sterols (Lechevalier \& Lechevalier 1988), a class of lipid that is

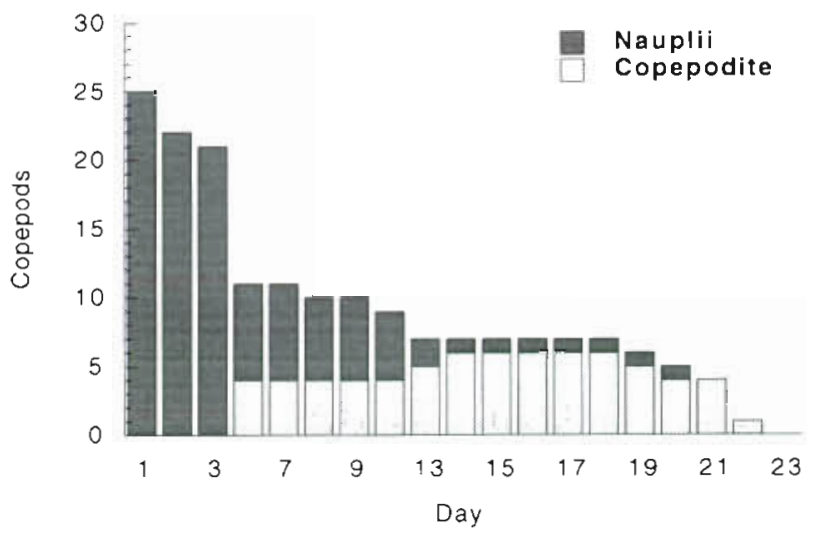

Fig. 4. Nitocra spinipes. Survival and development of 25 nauplii from a single clutch, reared separately in well-plates in filtored, autoclaved seawater. Plates were not examined on Days $4,5,11$, and 12

an absolute dietary requirement for the Crustacea (e.g. Goad 1981). We thus first set out to confirm this observation. In our experiment with the bacterial diet, we checked carefully to eliminate the possibility of contamination by protozoa. Since bacterial lipid content is so low $(<2 \%$ of dry weight), small numbers of protozoa could have contributed significantly to the lipid content of the diet even though they comprised a small fraction of the total caloric intake. Our results confirm that $N$. spinipes can indeed reproduce and grow on a strictly bacterial diet. Cannibalism and maternally derived energy stores could account for some, but not all, of the survivorship and growth. For example, the yield from our original 20 females in the bacteria-fed treatment was over 300 copepods, including over 100 that made it to the adult stage. Clearly, $N$. spinipes can convert bacterial food into more $N$. spinipes. How it obtains sterols under such conditions is not presently known. Possibly, it harbors gut symbionts that produce sterols, as do some insects (e.g. Douglas 1988). We also do not know how long this animal can continue to survive on a sterol-free diet. Further work rearing them through multiple generations is needed.

The results of our control in the feeding experiment, and of the starvation experiment, show that nauplii can develop to at least the early copepodite stages in filtered seawater. Since they are increasing in mass as they develop, they may be using dissolved organic matter (DOM). Direct uptake of DOM by copepods has been observed in several studies (Hicks \& Coull 1983, Poulet 1983), however, the mechanism and nutritional importance of this type of feeding behavior remain unclear. Again, the possible role of symbionts, either epibiotic or within the gut, is unknown.

Growth, development, and neutral lipid content were greatest in Nitocra spinipes when fed the relatively lipid-rich diatom Thalassiosira weissflogii. Our 
results suggest that diets rich in lipid maximize growth and lipid content in this species, as observed in a calanoid copepod (Hakanson 1984) and in several cladoceran species (Ahlgren et al. 1990). Lipid analysis of $N$. spinipes showed that $72 \%$ of the total neutral lipid in copepods fed the diatom was in the form of triacylglycerol, a storage lipid. This suggests that the lipid content of the diatom exceeded the daily metabolic demands of $N$. spinipes, permitting lipid storage to take place. No triacylglycerols were found in copepods raised on the other diets. For this copepod, living in a bacteria- and detritus-rich environment, where lipid content of the available food may often be low, the capacity to store lipids in the form of triacylglycerols may complement its apparently low lipid requirement.

Acknowledgements. We thank Dr K. Tenore for helpful discussion on the role of lipids in detritivore diets, Dr B. Coull for discussion of harpacticoid ecology, A. Gauzens for identification of Nitocra spinipes, and H. Milsaps and M. Ederington for hel.p in the laboratory. Financial support was provided by the National Science Foundation (REU program, award to Maryland Sea Grant; and OCE-90-12553)

\section{LITERATURE CITED}

Ahlgren G, Lundstedt L, Brett M, Forsberg C (1990) Lipid composition and food quality of some freshwater phytoplankton for cladoceran zooplankters. J Plankton Res 12(4):809-818

Alheit J, Scheibel W (1982) Benthic harpacticoids as a food source for fish. Mar Biol 70:141-147

Benson HJ (1990) Microbiological applications. Wm C Brown Publishers, Dubuque

Decho AW, Fleeger JW (1988) Ontogenic feeding shifts in the meiobenthic harpacticoid copepod Nitocra lacustris. Mar Biol 97:191-197

Douglas AE (1988) On the source of sterols in the green peach aphid, Myzus persicae, reared on holidic diets. J Insect Physiol 34:403-408

Durbin AG, Durbin EG, Wlodarczyk E (1990) Diel feeding behavior in the marine copepod Acartia tonsa in relation to food availability. Mar Ecol Prog Ser 68:23-45

Goad LJ (1981) Sterol biosynthesis and metabolism in marine invertebrat?s. Pure Appl Chem 51:837-852

Gopalan UK (1.977) Experimental mass culture of a harpacticoid copepod Nitocra spinipes Boeck. In: Qasim SZ (ed) Proceedings of a symposium on warm water zooplankton. Spec Publ UNESCO/NIO. National Institute of Oceanography, Goa, p 558-562

Hakanson JL (1984) The long and short term feeding condition in field-caught Calanus pacificus, as determined from the lipid content. Limnol Oceanogr 29:794-804

This article was presented by $K . R$. Tenore (Senior Editorial Advisor), Solomons, Maryland, USA
Harvey HR, Eglinton G, O'Hara SCM, Corner EDS (1987) Biotransformation and assimilation dietary lipids by Calanus feeding on a dinoflagellate. Geochim Cosmochim Acta 51: 3031-3040

Harvey HR, McManus GB (1991) Marine ciliates as a widespread source of tetrahymanol and hopan-3-ol in sediments. Geochim Cosmochim Acta 55:3387-3390

Heinle DR, Harris RP, Ustach JF, Flemer DA (1977) Detritus as food for estuarine copepods. Mar Biol 40:341-353

Hicks G, Coull BC (1983) The ecology of marine meiobenthic harpacticoid copepods. Oceanogr Mar Biol A Rev 21 $67-175$

Hobble JE, Daley RJ, Jasper S (1977) Use of Nuclepore filters for counting bacteria by fluorescence microscopy. Appl Environ Microbiol 33:1225-1228

Lang K (1948) Monographie der Harpacticoiden, Vol 2. Haran Ohlsson, Stockholm

Lazzaretto I, Salvato B (1992) Cannibalistic behaviour in the harpacticoid copepod Tigriopus fulvus. Mar Biol 113 $579-582$

Lechevalier H, Lechevalier MD (1988) Chemotaxonomic use of lipids - an overview. In: Rutledge C, Wilkereson SG (eds) Microbial lipids. Academic Press, New York, p $869-898$

Lee RF, Nevenzel JC, Paffenhöfer GA (1971) Importance of wax esters and other lipids in the marine food chain phytoplankton and copepods. Mar Biol 9:99-108

Muus BJ (1967) The fauna of Danish estuaries and lagoons. Meddr Dan Fisk- og Havunders NS 5 54-55

Noodt W (1970) Zur Ökologie der Copepoda Harpacticoidea des Kustengebietes von Tvarminne (Finnland). Act.a Zool Fenn 128:1-35

Parrish CC (1987) Separation of aquatic lipid classes by Chromarod thın-layer chromatography with measurement by Iatroscan flame ionization detection. Can J Fish Aquat Sci 44:722-731

Poulet SA (1983) Factors controlling utilization of non-algal diets by particle-grazing copepods. A review. Oceanologica Acta 6:221-234

Provasoli L, Conklin DE, D'Agostino AS (1970) Factors inducing fertility in aseptic Crustacea. Helgoländer wiss Meeresunters 20:443-454

Ranade MR (1957) Observations on the resistance of Tigriopus fulvus Fischer to changes in temperature and salinity J Mar Biol Ass UK 36:115-119

Rieper M (1978) Bacteria as food for marine harpacticoid copepods. Mar Biol 45:337-345

Rieper M, Flotow C (1981) Feeding experiments with bacteria, ciliates, and harpacticoid copepods. Kieler Meeresforsch 5:370-375

Volkman JK, Everitt DA, Allen DI (1986) Some analyses of lipid classes in marine organisms, sediments and seawater using thin-layer chromatography-flame ionisation detection. J Chromatogr 356:147-162

Wulff $F$ (1972) Experimental studies on physiological and behavioural response mechanisms of Nitocra spinipes (Crustacea: Harpacticoidea) from brackish-water rockpools. Mar Biol 13:325-329

Manuscript first received: May 1, 1995

Revised version accepted: August 25, 1995 